\title{
Large ciliary body melanoma
}

\author{
Basavaraj Tigari, Manu Saini 다, Shubham Manchanda, Santhosh Vankdoth
}

Advanced Eye Centre, Post Graduate Institute of Medical Education and Research, Chandigarh, India

Correspondence to Dr Manu Saini; manusaini.1024@gmail.com

Accepted 13 October 2021
Check for updates

(C) BMJ Publishing Group Limited 2021. No commercial re-use. See rights and permissions. Published by BMJ.

To cite: Tigari $B$, Saini $M$ Manchanda $\mathrm{S}$, et al. BMJ Case Rep 2021;14:e246386. doi:10.1136/bcr-2021246386

\section{DESCRIPTION}

A 58-year-old man presented with a 3-month history of painless blurred vision in the right eye. There was no antecedent history of trauma, flashes and floaters. Best-corrected visual acuity was 20/200 in the right eye and 20/30 in the left eye. Right eye intraocular pressure (IOP) was $9 \mathrm{~mm} \mathrm{Hg}$ and $10 \mathrm{~mm} \mathrm{Hg}$ in the left eye. Ophthalmic examination revealed the right eye superonasal pigmented mass at the equatorial region, spanning to cover half of the pupillary area, therefore, obscuring the examination of the disc and peripheral retina. There was no irregularity of anterior chamber depth, iris pattern alteration and no localised cataract were noted. Ultrasound examination disclosed a large ciliary body mass in the heart shape measuring $12.38 \mathrm{~mm} \times 6.8 \mathrm{~mm}$ dimensions and a typical tall spike with low-medium internal reflectivity of the lesion on A-scan (figure 1). His left eye examination was within normal limits. Medical history was unremarkable. Hereupon, metastatic workup was advised, including complete blood count, liver function test, renal function test, chest X-ray, ECG and Positron Emission Tomography (PET) scan study. His systemic investigations revealed no abnormality. Thus, with clinical and ultrasound consistent findings of large ciliary body melanoma, the patient underwent right eye enucleation and a primary implant. The histopathological examination of the right enucleated eye confirmed the ciliary body melanoma, with $1 \times 0.8 \times 0.5 \mathrm{~cm}$, showing sheets of the spindle to epithelioid cells comprising prominent nucleoli and abundant intracytoplasmic melanin pigment. The immunohistochemical stain was strongly positive for HMB-45 (figure 2).

Ciliary body melanomas are extremely rare and due to their hidden location usually present in the more advanced stage. The most frequent symptoms perceived are blurred vision, attributed to

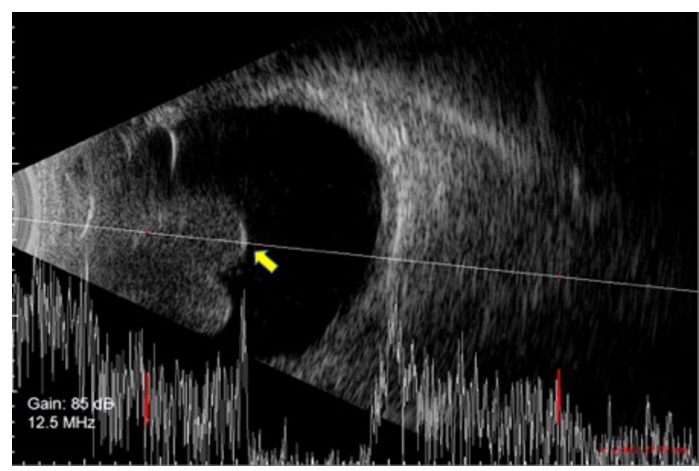

Figure 1 Ultrasound photograph showing a large bilobed, heart-shaped ciliary body mass $(12.38 \mathrm{~mm} \times$ $6.8 \mathrm{~mm}$ dimensions) on B-scan and low-medium internal reflectivity of the lesion on A-scan (arrow).

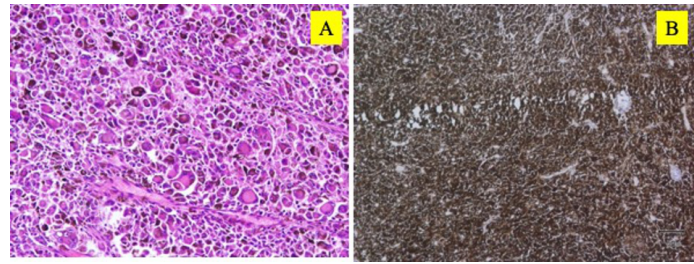

Figure 2 Photomicrograph of the mass showing sheets of the spindle to epithelioid cells with pigment on $\mathrm{H} \& \mathrm{E}$ staining, $40 \times(A)$ and strong positive immune stain with $\mathrm{HMB}-45$ (B).

\section{Learning points}

- Diagnostic dexterity is required to predict ciliary body melanoma as tumour is located in the hidden place.

- Long-term survival rate remains guarded in patients with the ciliary body melanoma, therefore lifelong follow-up seems prudent.

the astigmatism following displacement of lens, iris or painless visual field loss when advanced into the visual axis or painful decreased vision as a consequence of the sudden increase in IOP. ${ }^{1}$

The Hematogenous metastasis noted is at expeditious rate in the cilliary body melanoma attributed to the continuous contraction of the ciliary muscle, rich vascularisation of their anatomical region ${ }^{1}$ and their access to emissary canals, predisposes these tumours to the anterior or posterior extrascleral extension. ${ }^{2}$ However, metastasis at first presentation is uncommon with ciliary body melanoma, but eventual metastasis often occurs with this condition, perhaps in part because it grows in an area of the eye which is difficult to examine. A Diffuse growth pattern and large tumour size are the important determinants of metastasis, and histopathological mixed cell tumour comprising necrosis and epithelioid cells carry the worst prognosis. ${ }^{3}$

Our patient had a classic presentation of the ciliary body melanoma with interesting heartshaped configuration that was attributed to its bilobed presentation or differential growth perusal at the progressed end. A large size tumour diagnosis, before detection of any metastatic foci, helps in its primary management but despite being high precisison in diagnosis and its primary treatment, histopathological evidence of worst prognosis, the survival rate evolution remains unchanged. ${ }^{4}$

Contributors BT and SM contributed to the diagnosis, workup, writing the manuscript and performing critical revision. SV 
contributed to conducting the study, data acquisition and analysis, manuscript preparation and editing. MS holds the overall responsibility for the presentation and contributed to the diagnosis and performing critical revision of the manuscript.

Funding The authors have not declared a specific grant for this research from any funding agency in the public, commercial or not-for-profit sectors.

Competing interests None declared.

Patient consent for publication Consent obtained directly from patient(s)

Provenance and peer review Not commissioned; externally peer reviewed.

\section{ORCID iD}

Manu Saini http://orcid.org/0000-0003-4538-7803

\section{REFERENCES}

1 Costache M, Patrascu OM, Adrian D, et al. Ciliary body melanoma - a particularly rare type of ocular tumor. Case report and general considerations. Maedica 2013:8:360-4.

2 Seregard S, Kock E. Prognostic indicators following enucle- ation for posterior uveal melanoma. A multivariate analysis of long-term survival with minimized loss to followup. Acta 270. Ophthalmol Scand 1995;73:340-4.

3 Marigo FA, Finger PT. Anterior segment tumors: current concepts and innovations. Surv Ophthalmol 2003;48:569-93.

4 Singh AD, Shields CL, Shields JA. Prognostic factors in uveal melanoma. Melanoma Res 2001:11:255-63.

Copyright 2021 BMJ Publishing Group. All rights reserved. For permission to reuse any of this content visit

https://www.bmj.com/company/products-services/rights-and-licensing/permissions/

BMJ Case Report Fellows may re-use this article for personal use and teaching without any further permission.

Become a Fellow of BMJ Case Reports today and you can:

- Submit as many cases as you like

- Enjoy fast sympathetic peer review and rapid publication of accepted articles

- Access all the published articles

- Re-use any of the published material for personal use and teaching without further permission

Customer Service

If you have any further queries about your subscription, please contact our customer services team on +44 (0) 2071111105 or via email at support@bmj.com.

Visit casereports.bmj.com for more articles like this and to become a Fellow 